\title{
An Epistemic Case for Legal Moralism
}

\author{
ROBERT E. GOODIN*
}

\begin{abstract}
Ignorance of the law is no excuse, or so we are told. But why not? The statute books run to hundreds of volumes. How can an ordinary citizen know what is in them? The best way might be for law (at least in its wide-scope duty-conferring aspects) to track broad moral principles that ordinary citizens can know and apply for themselves. In contrast to more high-minded and deeply principled arguments, this epistemic argument for legal moralism is purely pragmatic - but importantly so. For law to do what law is supposed to do, which is to be action-guiding, people need to be able to intuit without detailed investigation what the law is for most common and most important cases of their conduct, and to intuit when their intuitions are likely to be unreliable and hence that they need to investigate further what the law actually is.
\end{abstract}

'Legal moralism' is the doctrine that law should track morality. Many high-minded defences of that doctrine have been offered over the years. Here I shall offer a partial defence of the doctrine, couched purely in terms of low pragmatism: tracking morality enables the law to do what law is socially supposed to do, which is to guide people's behaviour. ' 'Guiding' here involves both 'pointing' and 'pushing'. The social function of law is not just to tell people what they should do, but also to provide them with extra inducements, sanctions and incentives, actually to do as prescribed.

The classically high-minded case for legal moralism is couched terms of 'the priority of morality'. In the boldest version of that doctrine, the natural lawyer claims that morality is literally constitutive of legality. Divine commands in the old days or moral imperatives of a more secular sort in our own day are, on this account, what make laws law. The job of legislators is merely to copy those faithfully into the statute books. When they fail (as occasionally they inevitably

* Distinguished Professor of Social \& Political Theory and of Philosophy, Research School of Social Sciences, Australian National University. Email: goodinb@coombs.anu.edu.au. An earlier version of this article was delivered as the 2008 Dewey Lecture in Law and Philosophy at the University of Chicago Law School. I am grateful for comments from Mary Anne Case, Tom Christiano, John Deigh, Richard Epstein, John Gardner, Jake Gersen, Al Hajek, Heidi Hurd, John Kleinig, Nelly Lahoud, Saul Levmore, Judy Lichtenberg, Sue Mendus, Michael Moore, Martha Nussbaum, Eric Posner, Houston Smit, Nic Southwood, Cass Sunstein, Larry Temkin, Robin West, Lea Ypi and other seminar participants at the law schools of University of Chicago, ANU and Georgetown University.

1 As LL Fuller, Anatomy of the Law (Penguin, Harmondsworth 1971) 88 puts it, our aim 'in making law is to lay down rules by which people may guide their conduct'. That is its social function anyway; any particular lawmaker might have other aims of his own, which might sometimes conflict with that, as Fuller goes on to observe.

(C) The Author 2010. Published by Oxford University Press. All rights reserved. For permissions, please e-mail: journals.permissions@oxfordjournals.org 
must) and they write something contrary to natural law into a statute, it is not really law at all.

A more modest version regards morality not as constitutive of legality but rather as a critical standard for assessing laws. Moral considerations are the ultimate right-makers and wrong-makers. Stipulations of what is right and wrong at law ought correspond to (or anyway not contradict) the right-makers and wrong-makers of morality itself. Legal stipulations that are contrary to morality's dictates are nonetheless laws: they are merely 'bad laws,' criticizable from the standpoint of ethical standards that stand morally above the law.

Either of those propositions may be true, too. But here I want to make a case for legal moralism that is far less lofty. It centres around the much more pragmatic question, 'How can we know what the law requires of us?' After all, as Bentham observed, 'A law that is unknown can have no effect... '2 It can do nothing to guide, point or push us.

There are various answers possible to the question of how we can know what the law requires of us. I shall argue, however, that for the great bulk of wide-scope, duty-imposing laws, the most plausible answer is for laws to be written in such a way that they track broad, general principles of morality. ${ }^{3}$ Whatever other high-minded reasons there may be for law to track morality, there is always that lowly pragmatic reason for it to do so, purely in order to maximize citizens' epistemic access to the content of the law, and in that way to enable law to serve its social function of guiding their behaviour.

\section{1.}

Ignorantia juris non excusat: ignorance of the law is no excuse. So we are told by virtually every criminal code from Roman times forward. ${ }^{4}$

But why on earth not? After all, the US Code runs to some 364 bound volumes. How can I possibly know everything in it? Add to that all the state laws-Indiana's Burns Statutes runs to 43 volumes, which I suppose is probably pretty typical. Add to that all the city and county ordinances-I do not even know where to find those to count them. Add administrative regulations from scores of federal, state and municipal agencies. No one can possibly know all the laws that apply to him. Ignorance of the law is, to some greater or lesser extent, simply unavoidable.

\footnotetext{
2 Jeremy Bentham, 'The Theory of Legislation' in $\mathrm{R}$ Harrison (ed), Selected Writings on Utilitarianism (Wordsworth, Ware 2000) pt I, ch 17, 373.

${ }^{3}$ My point is thus an epistemic rather than motivational one. That the law tracks their sense of justice may also explain 'why people obey the law'; see TR Tyler, Why People Obey the Law (Yale UP, New Haven 1990). But my concern here is different from that: it is instead with the separate question of 'how people know the law'.

${ }^{4} \mathrm{~W}$ Blackstone, Commentaries on the Laws of England (Clarendon Press, Oxford 1769) vol 4, ch 2, sec 6, 27; ER Keedy, 'Ignorance and Mistake in the Criminal Law' (1908) 22 Harvard L Rev 75-96; G Williams, Criminal Law (2nd edn Stevens \& Sons, London 1961) ch 8.
} 
Of course, there are all sorts of pragmatic reasons for insisting that 'ignorance of the law is no excuse', regardless. We find one in John Selden's seventeenth-century 'Table Talk': 'Ignorance of the Law excuses no Man; not that all Men know the Law, but because 'tis an excuse every man will plead, and no Man can tell how to confute him. "5 In consequence, John Austin adds, the courts would be hopelessly congested if they had to explore all the claims that would inevitably be lodged, if ignorance of the law were to be accepted as an excuse. ${ }^{6}$ Furthermore, as Holmes observed, admitting that excuse would perversely provide people with an incentive to remain ignorant of the law. ${ }^{7}$

In practice, and notwithstanding the general rule, ignorance often is taken to excuse conduct contrary to law. That can happen, for example, in cases involving a regulation rather than a statute, or an omission rather than an action, or where the accused has relied on an authoritative (but as it happens mistaken) source of information about the law, or where the subject matter is unlikely to have been regulated by law; or if the statute does not serve any important purpose. Of course, we do not generally tell people that ignorance of the law will probably be excused in such cases-instead, for the pragmatic reasons just given, we let them continue to believe ahead of time that 'ignorance is no excuse'. ${ }^{8}$

From the point of view of natural justice, it is only right that illegal acts be excused where people did not and could not know the law at the time they acted. It might be similarly good from the perspective of natural justice that illegalities be excused where people had no reason to suppose there might be a law on the matter, the details of which they should have ascertained.

As JL Austin said of 'excuses' in general, however, they have a way of getting you out of the fire and into the frying pan. ${ }^{9}$ Such circumstances obtaining is genuinely bad news, from the point of view of the social function of law. If people have no reason to suppose there might be a law on the matter, then it is highly unlikely that their conduct will be guided by that law. In that case, the law fails to fulfil its central social function to be action guiding.

I take it as axiomatic not only that law is supposed to be action-guiding but also that it is supposed to guide action in a relatively 'no fuss' manner. That is

${ }^{5}$ J Selden, 'Table Talk' in J Thornton (ed) Table Talk from Ben fohnson to Leigh Hunt (Dent, London 1934) ch 77 , sec 2, 60, quoted in Williams (n 4) 290.

6 ' $[\mathrm{T}]$ he Courts would be involved in questions which it were scarcely possible to solve, and which would render the administration of justice next to impracticable. If ignorance of law were admitted as a ground of exemption, ignorance of law would always be alleged by the party, and the Court, in every case, would be bound to decide the point', J Austin, Lectures on furisprudence (John Murray, London 1879) 498; see more generally Lect 25, vol 1, 496-501. See also LD Holgate, 'Ignorantia furis: A Plea for Justice' (1967) 78 Ethics 32-42, at 37.

7 OW Holmes Jr, The Common Law (MDW Howe (ed) Little Brown, Boston 1963) 41.

${ }^{8}$ We strive for something like an 'acoustic separation' between the 'conduct rules' by which the folk are supposed to behave and the 'decision rules' by which the courts are supposed to assess their conduct, come to cases, in the words of Meir Dan-Cohen, 'Decision Rules and Conduct Rules: On Acoustic Separation in Criminal Law', (1984) 97 Harvard L Rev 625-77, at 645-8.

9 JL Austin, 'A Plea for Excuses' in Philosophical Papers (3rd edn Clarendon Press, Oxford 1979) 177. 
to say, people ought by and large be able to determine and apply the law to and for themselves, without constant recourse to courts and counsellors and constables. ${ }^{10}$ Laws that require constant interpretation and enforcement may still perform some useful social function. But they serve that function at considerably more social cost than ones that are more nearly self-interpreting and self-enforcing.

\section{2.}

In his attempt at teasing out the 'minimal content of natural law', HLA Hart invites us to consider

what is in fact involved in any method of social control-rules of games as well as law-which consists primarily of general standards of conduct communicated to classes of persons, who are then expected to understand and conform to the rules without further official direction. If social control of this sort is to function, the rules must satisfy certain conditions. ${ }^{11}$

Hart goes on to list some: the rules must be 'intelligible'; they must ordinarily 'not be retrospective'; and so on. ${ }^{12}$

But those are merely the limiting cases. Of course it is literally impossible for people to 'understand and conform' to a rule that is does not (yet) exist or that is literally 'unintelligible'. But the method of social control Hart has in mind does not merely require that it be possible for people 'understand and conform to the rules without further official direction': it further requires that it actually be probable (common, likely) that they will do so.

In ordinary discussions of these topics, emphasis falls heavily upon 'possibility conditions'. It falls most especially on the requirement that a law must be promulgated to serve as law. If a law has not been promulgated, ordinary citizens will have no way of knowing it is a law, and it is therefore impossible for them to guide their behaviour by it. ${ }^{13}$

Suppose, however, that a law has been promulgated but in only the most minimal of ways. Suppose it was announced in some official register only a few copies of which were printed, or in some courtly language the general populace does not understand. While it would no longer be literally impossible for people to come to know that law, in a way it would have been had the law not been promulgated at all, it is nonetheless highly unlikely that they would come to know the law or hence guide their behaviour by it. A barely promulgated law

10 That is implicit in desideratum in Fuller's Anatomy of Law (n 1) 88 and explicit in Hart's statement of it quoted in full below. As Bentham put it in 'The Theory of Legislation' (n 2) pt I, ch 17, 375, 'the law ought to be a manual of instruction for each individual; and everyone should be enabled to consult it... without the aid of an interpreter.'

11 HLA Hart, The Concept of Law (Clarendon Press, Oxford 1961) 202.

12 Borrowing from LL Fuller, The Morality of Law (rev edn Yale UP, New Haven 1969).

13 They might do what the law requires without knowing that that is what the law requires: but that is something different. 
fails to perform the social function of law, to almost the same extent and for exactly the same reason as a law that has not been promulgated at all.

Notice also that maximizing promulgation is not necessarily the best way to maximize the extent to which people 'know what the law is'. Providing every US household with a copy of the US Code-all 364 volumes of it - might maximize promulgation. Doing that would maximize the extent to which people could possibly access the law. But doing so would do little to increase the probability that they would actually know the law.

Lawyers are rightly sensitive to the importance of promulgation. But the problem here in view is not one that can be solved by promulgation. The problem is that there is simply too much law there for people to sift through. Giving everyone a copy of the US Code, or putting it all on the internet, will not help with that. The problems are the same searching so much text electronically as working through a hard-copy index. In conducting a search of either sort, the problem is simply that you don't know what you don't know.

\section{3.}

Historically (going way back) the principal reason ignorance of the law was not accepted as an excuse was presumably that the law was deemed to be something that everyone knows-or anyway (more recently) that that was something that everyone could and should be presumed to know. ${ }^{14}$

The first formulation - that the law is something that everyone knowsmight have been true, and virtually analytically so, in primitive legal systems where 'customary law' was the only kind of law there was. In a system of customary law, something counts as a legal requirement if and only if it corresponds to the customary practice of a people. And, obviously, people know their own customs: they are 'second nature' to them. ${ }^{15}$ As Bentham puts it,

how a custom ... is to be known, is a question, which upon the supposition that it is the custom of the people in general, ... seems neither very natural nor very material. How is it to be known? meaning by the people? Why, they know it, by the

\footnotetext{
14 In the words of Blackstone's Commentaries (n 4) vol 4, 2, 'a mistake in point of law, which every person of discretion not only may, but is bound and presumed to know, is in criminal cases no sort of defence'.

${ }^{15}$ In Savigny's phrase, quoted in J Waldron, 'Can There Be a Democratic Jurisprudence? (2008-09) 58 Emory L J 675-712, 692. See also DR Kelley, The Human Measure (Harvard UP Cambridge, Mass 1990) chs 10-13. This gives rise to a view of 'ideal community law', according to which 'the law [is] the common way, the common tradition of the people.... According to it, the need to promulgate the law is no more than a requirement of clarifying its details. The law should be applied by people who rely not only on skills acquired by formal training but on sharing the traditions of the community. They belong to the same community, come from the same background as the litigants, and rely on local knowledge which cannot be proved in court and cannot even be fully articulated in a reasoned judgment'; J Raz, Ethics in the Public Domain (Clarendon Press, Oxford 1994) 371.
} 
supposition; they even practice it, it is their custom. 'How are the people to know what it is they do themselves?' God knows, unless they already know. ${ }^{16}$

It is not quite as analytic as that makes it sound that people necessarily know their own customary law. People might customarily do something unreflectively, so they might not consciously realize that it is customary practice. Even knowing that it is customary practice, they might still not know that that makes it law as well (they may never have heard of the concept of 'customary law'). So it does not quite analytically follow that people in general must necessarily know what customary law requires. Still, it is likely that they will do so, at least in smaller and simpler societies.

That almost-analytic guarantee disappears as we move away from purely customary law toward systems that include edicts, statutes, administrative orders and judicial precedents. At that point, the proposition that everyone actually knows what the law requires becomes wildly implausible, and emphasis shifts toward the very different proposition that everyone could and should know what the law requires. ${ }^{17}$

Considerable scorn has been heaped on that proposition over the years. John Austin was blistering:

That Law might be knowable by all those who are bound to obey it, or that Law ought to be knowable by all those who are bound to obey,... is, I incline to think, true. That any actual system is so knowable, or that any actual system has ever been so knowable, is so notoriously and ridiculously false that I shall not occupy your time with proof of the contrary. ${ }^{18}$

Lord Mansfield wryly observed that 'it would be very hard upon the [legal] profession, if the law was so certain, that everybody knew it': lawyers could not make any money that way. ${ }^{19}$ Another jurist acidly remarked that 'everybody is presumed to know the law except His Majesty's judges, who have a Court of Appeal set over them to put them right'. ${ }^{20}$ And today, of course, 'the idea that the vast network of governmental controls can be known by everyone is ... more ludicrous than ever'. ${ }^{21}$

However, even in Roman times 'the rule as to ignorantia juris did not apply to certain classes of individuals... because it was considered that these individuals, by reason of their status or condition, would not have knowledge of the

\footnotetext{
$16 \mathrm{~J}$ Bentham, A Comment on the Commentaries and a Fragment on Government (JH Burns and HLA Hart (eds) Athlone Press, London 1977) 92.

17 One of the most fanciful rationales for that comes from Blackstone: 'every man in England is, in judgment of law, party to the making of an act of parliament, being present thereat by his representatives' (quoted in Fuller (n 1) 81).

18 Austin, Lectures on Furisprudence (n 6) Lect 25, 497.

19 fones $v$ Randall (1774) Cowp 37, 40; 98 ER 954, 956, quoted in Williams (n 4) 290.

20 Justice Maule, quoted in Williams, ibid.

21 Williams, ibid. See similarly EN Griswold, 'Government in Ignorance of the Law: A Plea for Better Publication of Executive Legislation' (1934) 48 Harvard L Rev 198-215.
} 
law'. ${ }^{22}$ Among people thus exempted were those under age 25, women, soldiers, peasants and the mentally infirm. Note significantly, however, that they were exempt only in respect of the jus civile, not the jus gentium. The rationale was that, while their condition or status might be such that they could not be expected to know the details of the particular jus civile, 'the jus gentium is knowable naturali ratione' by everyone whatever their status or condition. ${ }^{23}$

Glanville Williams proposes we resurrect that ancient practice and adapt it to the circumstances of the modern regulatory state. 'A distinction should be drawn', Williams suggests,

between crimes resting upon immemorial ideas of right and wrong, where it is the business of the citizen to know what he may legally do, and modern regulatory offences of which the citizen would not normally know unless there is something to put him on enquiry..... Moreover, the principle of German jurisprudence could be adopted that the defendant is required to have exerted his conscience properly, making enquiry as to the law where a conscientious person would have done so. ${ }^{24}$

\section{4.}

I agree with the old Roman law and with the principle of German jurisprudence that Glanville Williams commends on the basis of it. There are certain sorts of people and certain sorts of activities that are governed by very specific laws, details of which the people concerned could and should be expected to ascertain for themselves.

Here are two large classes of such cases:

(i) Many rules of law are power-conferring rather than duty-imposing. Hart's examples are 'rules such as those prescribing the procedures, formalities and conditions for the making of marriages, wills, or contracts'. ${ }^{25}$ When you set about invoking powers under law-writing a will that will be enforceable in court, for example-you must know that there is some law that you are trying to manipulate. Furthermore, you should know that you need to check the details of that law to ensure that you invoke it efficaciously. ${ }^{26}$ There is no obviously correct way to write a will, which you can derive from first principles while sitting in your

${ }^{22}$ Keedy (n 4) 80.

23 Austin, Lectures on Furisprudence (n 6) Lect 25, 501, quoted in Keedy, ibid. Neither are people quite generally expected to know the jus civile of foreign jurisdictions: 'Ignorance of law, within the meaning of the rule that ignorance of law will not excuse, is to be construed as meaning ignorance of the laws of one's own country or state, not laws of foreign countries or states, which are regarded as mistakes of fact' (Marshall v Coleman $58 \mathrm{NE}$ 628, 637, 187 Ill. 556 [1900]).

24 Williams (n 4) 292.

25 Hart (n 11) 9 and ch 3 generally.

${ }^{26}$ As Austin, Lectures on Furisprudence (n 6) Lect 25, 501 observes, 'A Common Law lawyer, if he were making a will or a settlement of real property, would, if he acted rationally, surmise that there must be provisions of the law of real property which were not known to him, and would accordingly have recourse to a conveyancer, rather than foolishly attempt to draw the instrument for himself.' 
armchair. There are many equally good ways that that law might have been specified. The exact form of words required to make a will legally effective around here is simply something you have to go look up.

(ii) Many rules of law are not wide-scope, applying to people in general, but rather narrow-scope, applying only to people who occupy very specific roles. Lon Fuller agrees with my initial observation about the vast array of laws on the books: 'an expectation that the dutiful citizen will sit down and read them all' would be 'an absurdity'. But Fuller thinks that that absurdity is mitigated by the fact that 'the great bulk of modern laws relate to specific forms of activity, such as carrying on particular professions or businesses; [and] it is therefore quite immaterial that they are not known to the average citizen'. ${ }^{27}$ Anyone who is occupying a very specific social role could and should imagine that there might be specific legal powers and duties attaching to that role, and could and should take steps to ascertain what they might be. And while the details of some of those laws might be surmised from the armchair, many of them might admit of several equally good specifications; and once again, you simply have to go look up which one actually got written into the law around here.

In terms of the old Roman model, these can be seen as two groups of people who need to know, and can reasonably be expected to know they need to know, the jus civile: the particular laws that apply to them in their particular roles or that govern the particular legal powers that they are trying to invoke.

For purposes of the present discussion, I am unconcerned with those people for two reasons. First, given their special situations, it should be obvious to them that there is indeed some particular law applying to them that they need to ascertain. ${ }^{28}$ Second, the content of the law that governs such special situations is likely to be correspondingly special, and often inevitably somewhat arbitrary. The exact specification that actually got written into the statute book is something they simply have to go look up.

5.

My concern is instead with the great bulk of people in general, and how best to give them epistemic access to the content of the great bulk of the wide-scope duty-imposing rules of law under which they live. By 'wide-scope' I mean 'outside any specific role' which give rise to special 'narrow-scope' rules of its own. By 'duty-imposing' I mean rules of law that are not 'power-conferring,' thus bracketing situations in which people are knowingly trying to manipulate legal instruments themselves. By 'epistemic access' I mean 'enabling them to

27 Fuller (n 12) 51. See similarly Williams (n 4) 292.

${ }^{28}$ Pace the Supreme Court's ruling in Lambert v California 355 US 225 (1957), nowadays anyway even a convicted felon ought realize that that is itself a 'special role' and special duties, such as registering with the police, might attach to it; they had better check. 
know the content' of the rules of law governing them. My argument is that law's tracking morality is the best practical means for giving people in general epistemic access to what the great bulk of wide-scope duty-imposing law requires of them.

Maybe that strategy cannot give people access to absolutely all of even that large subset of the law. In some highly complex situations morality might be silent on some subject that law needs to settle, or there might be multiple ways of settling it that are equally morally appealing. There, too, people will simply have to go look up what the law requires, rather than trying to surmise what the law is from reflecting upon what morality requires. Still, even if morality cannot be a complete guide to the content of the law, even in its wide-scope duty-imposing guise, law tracking morality wherever it can would give people good guidance as to the content of the law in the great bulk of cases. In any event, the issue is not whether it can be a perfect guide but whether any other guide can do better.

The classic (although far from only) case of wide-scope duty-imposing law is of course the criminal law. How do we know what is against the criminal law? Well, sometimes it comes up in the course of ordinary conversation; sometimes we know or read about someone who has been prosecuted for breach of some law. But by and large we simply surmise what is wrong, at law, from our knowledge of what is wrong, morally.

Crimes, Glanville Williams remarks, rest 'upon immemorial ideas of right and wrong. ${ }^{29}$ Those function as the modern equivalent of the Roman jus gentium. Everyone has access to them, and 'it is the business of the citizen to know what he may legally do', in consequence.

Indeed, reflecting upon the moral is our ordinary way of surmising the criminal. That is so obvious that it is often overlooked. ${ }^{30}$ Notice this passage in Fuller's Anatomy of the Law:

Suppose a citizen wants to know whether some act he proposes to do is criminal. We are assuming that the question arises in an area of conduct where ordinary standards of moral behavior are an insufficient guide. ${ }^{31}$

Fuller goes on to discuss the case of an owner of a newspaper stand trying to decide if it is legal to keep his stand open on some public holiday. ${ }^{32}$ But for present purposes, focus just upon the passage quoted.

How it could be that the citizen is puzzled as to what the criminal law requires? Well, as Fuller says, 'We are assuming that... ordinary standards of moral behavior are an insufficient guide' in the case at hand. But that implies

\footnotetext{
29 Williams (n 4) 292.

30 For example, J Hall, General Principles of Criminal Law (2nd edn Bobbs-Merrill, Indianapolis 1960) 278 remarks in passing 'the criminal law represents certain moral principles'.

${ }^{31}$ Fuller (n 1) 17.

32 That example, notice, concerns a narrow-scope law, applying to him in that very particular role, rather than wide-scope, applying to everyone in general.
} 
what is here my main point: that our first recourse, in trying to decide what the criminal law requires, is to reflect upon 'ordinary standards of moral behaviour'. That is our first, best guide. Only when that is an insufficient guide - only when morality is silent or unclear or confused or contested-do we make further enquiries as to what the criminal law actually requires.

The criminal law is just the most dramatic example of wide-scope duty-imposing law, however. The same thing that is true of it is true, to a lesser extent, of all other instances of that type of law. Among them is tort law.

Of course, as I have said, highly complex situations can upon occasion arise even within criminal law, such that reflecting upon what is morally appropriate provides no clear guidance as to what might be legally required. Such complexities might arise even more frequently in tort law. In such cases, people simply have to go check the law books once again. But the fact that we cannot morally intuit what is legally required in some highly complex situations ought not obscure the fact that, in much the most common cases in both criminal and tort law, law could — and for maximum epistemic advantage should-be written around simple moral principles that can provide people with clear guidance as to what the law is likely to be.

\section{6.}

For people to have good epistemic access to the content of the law, what is needed is:

(i) A way for people to intuit, without detailed investigation, what the law is for most common and most important cases of their conduct; and

(ii) A way for people to intuit when their intuitions are likely to be unreliable, and hence that they need to investigate further what the law actually is.

Letting the wide-scope duty-imposing rules of law track morality is, I claim, a good way of accomplishing both.

It is easy to see that this is true, as regards the first desideratum. If law tracks morality, in cases where moral sentiments are univocal and strong people do not need to look up the law in some big book. They need simply ask themselves, 'What should the law be on this subject?' If law tracks morality, they can just assume that that is what the law is on that subject. Furthermore, insofar as the same moral sentiments are widely shared across the community, that will be 'common knowledge' across the community: I know that you know that that is what the law is; you know that I know that you know; and so on.

This crucially assumes that people generally know what is morally right and wrong - or at least that they have better epistemic access to that than they do to what is legally required. That is an empirical speculation, to be sure. Like all empirical claims, it might turn out to be false-in which case my epistemic 
argument for law to track morality will fail. But empirically, that claim surely is highly likely to be true. After all, it is as Hart says

an essential feature of any moral rule or standard that it is regarded as something of great importance to maintain.... [This] is manifested in [among other things] ... the serious forms of social pressure exerted not only to obtain conformity in individual cases, but to secure that moral standards are taught or communicated as a matter of course to all in society. ${ }^{33}$

By tracking morality, law can piggyback on all that apparatus already in place for promulgating the moral code.

Of course, knowing what morality requires is one thing, doing what morality requires is quite another. People often know what is morally the right thing to do, but just cannot bring themselves to do it, for one reason or another. That explains why there might be some practical point in superimposing a legal requirement over and above the moral one. Far from merely telling people to do something they would have done anyway, backing morality with the force of law gives people extra incentives (legal rewards and punishments) to do what is morally prescribed. Legalizing morality is, alas, far from redundant.

The second desideratum is that there should be a way for people to intuit when their intuitions are likely to be unreliable, as regards the content of the law. I have already discussed two such cases: when they are dealing with power-conferring rules of law, or with narrow-scope rules of law applying to them in some very particular role. Now I want to move beyond that, to cases where people need to be able to intuit when their intuitions are likely to be unreliable, even as regards duty-imposing wide-scope rules of law, like the criminal code.

Here is one way. Suppose law tracks morality. But suppose that morality is (and is known to be) unclear or contested on the point in question. Joseph Raz thinks this is a problem for the thesis that law should track morality: there is in the case in view no single, settled moral judgment for it to track. ${ }^{34}$ But that is more of a worry for high-minded legal moralists. Let us look at the situation instead from an epistemic angle, thinking of morality as merely an indicator of what the law is likely to be. If there is no clear moral ruling on the situation, then neither can there be any strong inference from morality as to what the legal rule is likely to be. As with someone occupying a special role or invoking a legal power (writing a will, for example), someone wanting to know what the law is on that point will simply have to go look at the statute books. Furthermore, and more importantly, someone in that position should know from the sheer fact that morality is unclear or contested on that point that he or she needs to go look at the statute books.

\footnotetext{
33 Hart (n 11) 169.

${ }^{34}$ Raz (n 15) 373.
} 
My proposal, then, takes the form of two pieces of advice, one for legislators and the other for citizens:

- From the point of view of legislators, the question is 'what should be legally prescribed or proscribed?' My recommendation there would be that law should insofar as possible track morality in its most general form. ${ }^{35}$ In this way, citizens would have maximal epistemic access to the content of the law under which they live. ${ }^{36}$

- From the point of view of citizens, the question is 'what might be legally prescribed or proscribed?' My recommendation there would be for them to apply a two-fold test. Firstly ask yourself, 'What do you think is immoral?' Secondly ask yourself, 'What do others around here think is immoral?' If those two judgments converge-and if you have reason to believe that lawmakers have taken my first piece of advice-then you can pretty safely assume that that is what the law requires as well. But insofar as judgments about what is immoral diverge, you had better go look up what the law actually requires. Any of those diverging moral judgments, or any compromise in between, might have got written into the statute book. $^{37}$

7.

Does this just amount to a suggestion that we revert to customary law? Well, it does, if the morality you write into the law code is purely positive morality, the conventional rules of society as you find them. It does not, if the morality you write into the law code is critical-normative morality, what is 'really right and good' independently of what people at any particular time or place say that to be.

It might be thought that the epistemic argument I have been developing most naturally seems to incline toward writing purely positive-conventional morality rather than critical-normative morality into the law. After all, it is the

\footnotetext{
35 For the moment, I shall leave as an open question whether law should track critical-normative morality or positive-conventional morality and, in the case of multiple and partially conflicting conventional positive moralities within a community, the 'overlapping consensus' among them. On the latter, see J Rawls, Political Liberalism (Columbia UP, New York 1993) Lect 4 2001, \$11.

36 Commenting on Law Commission proposals for reform to the much-maligned Offences Against the Person Act 1861, J Gardner similarly pointed 'to the demands of the rule of law in at least one vital respect,' that laws 'have a good dose of the moral clarity which makes them accessible to the ordinary people who must be guided by them', 'Rationality and the Rule of Laws in Offences Against the Person' (1994) 53 Cambridge LJ 502-23, 516.

37 Of course, if legislators faithfully enact only the content of the overlapping consensus within their community, no citizen would need to ask herself the second of those questions. The answer to the first alone would, in that case, be fully determinative. I shall argue in the next section, however, that there are reasons for law to track critical normative morality rather than conventional positive morality, or hence just the overlapping consensus among multiple conventional positive moralities.
} 
positive-conventional morality to which everyone in the community has most immediate epistemic access. ${ }^{38}$

But at this point Hart's question gives us high-minded moralistic reason pause: 'Does the morality with which law must conform... [really] mean the accepted morality of the group whose law it is, even though this may rest on superstition or may withhold its benefits and protection from slaves or subject classes? ${ }^{39}$

One response would be to say that different arguments for legal moralism simply pull in different directions. On that account, the pragmatics of maximizing epistemic access to the law would indeed recommend letting law track positive morality, however wicked. There would be epistemic costs in deviating from that. But from the perspective of the more high-minded forms of legal moralism, those epistemic costs would be well worth bearing. High-minded legal moralists would insist that law ought track the requirements of critical-normative morality, however unfamiliar people might find them. Of course, those laws would then have to be promulgated and well-publicized; people there could not easily intuit them. But so much the better, the high-minded legal moralist would say. The law would then be giving people a valuable moral education.

Maybe we cannot do that too often, without undermining the folk's faith in morality as they currently perceive morality as a good guide to the content of the law. But perhaps we do not need to do it too often. Perhaps more often than not, we can allow law to track positive-conventional morality without great (critical-normative) moral cost.

I think that that first response is a perfectly good response. After all epistemic costs are merely epistemic costs. There are alternative ways of giving people epistemic access to the content of the law, other than letting people surmise that on the basis of what they (think they) know about the requirements of positive-conventional morality. Those alternatives are more costly and cumbersome. But if there is some good critical-normative reason for pursuing those alternatives, we can and should do so from time to time, rather than letting law track positive-conventional morality where it is seriously perverse.

To that first response, however, let me add a second. This is a response that, if successful, would tip the scales of that tradeoff even more heavily toward critical-normative morality—and it would do so for purely epistemic reasons.

The thought is just this. Maybe it is better to let law track critical-normative morality rather than purely positive-conventional morality, for the same reason

\footnotetext{
38 JS Mill, eg argues that 'when an Englishman in India... borrows or lends, or enters into contracts of any other kind with natives, he must be understood to do so according to the native laws' because those are 'the only ones which are known to the parties he contracts with', 'Minute on the Black Act' in Writings on India (JM Robson, M Moir and Z Moir (eds) U Toronto Press and Routledge, Toronto 1990) 13.

39 Hart (n 11) 201.
} 
that the common law is better than customary law. Common law is really just 'the customary law among judges'. But what makes the customary law of judges superior to the customary law among the folk is that the judiciary feels obliged to bring its practice under some principles, to treat similar cases similarly and to treat different cases differently only in proportion to the extent in which they differ in ways that matter to the principles underlying the rule.

Of course, the principles that common law judges elaborate quickly become quite complex. There is more little chance that any citizen could know everything in the 30-odd volumes of the Restatement of the Law than there is that he or she could know everything in the 364 volumes of the US Code. If citizens are to surmise the law for themselves, they need something far simpler and more straightforward than the plethora of principles that judges have written into the common law. ${ }^{40}$ Still, it is certainly easier to work out common law from first principles than it is to work out statutory law from first principles. There is simply no telling what might get into the heads of legislators some late-night sitting.

In similar fashion, it is easier to work out critical-normative morality from first principles than it is to work out positive-conventional morality from first principles. The customary moral practices in any particular place have a long history of assorted accretions. There is little rhyme or reason to many of them. Like statutory law, you simply have to learn them off by heart. If there are gaps in your knowledge of them, there is little you can do to fill in the missing elements by adducing them from what all else you know about customary moral practices.

Critical-normative morality, in contrast, is (arguably) organized around a small set of fundamental principles, precisely so people can work out for themselves what morality requires of them. ${ }^{41}$ After all, there are no moral courts to issue authorized interpretations of morality's edicts. Critical-normative morality must be structured in such a way that by and large people are able to work its edicts out for themselves.

If we think law should track morality, purely for the pragmatic reason that in that way citizens will be given better epistemic access to the content of the law, then it is those simpler and more readily accessible principles of criticalnormative morality that it should track. Purely positive-conventional morality is

40 As Bentham railed in 'The Theory of Legislation' (n 2) pt I, ch 17, 374, 'The English Common Law ... is so complicated in its provisions regulating the descent of property, it admits of distinctions so singular, the decisions which serve to regulate it are so subtle, that not only is it impossible for simple good sense to presume its regulation beforehand, but it is very difficult to discover them all'.

${ }^{41}$ Bentham, 'Introduction to the Principles of Morals and Legislation' ch 2, sec 12, 101-2 in Harrison (n 2), recommended the 'principle of utility' as such a critical normative standard, saying, 'What one expects to find in a principle is something that points out some external consideration, as a means of warranting and guiding the internal sentiment of approbation and disapprobation'. Critical-normative morality organized around such principles contrasts, Bentham says, with commonsense positive moralities which simply 'hold up each of those sentiments as a ground and standard for itself'. 
less predictable, less straightforwardly derivative from any first principles. It is less epistemicly accessible to people in consequence, and less epistemicly suitable as a basis for the law for that reason.

\section{8.}

So far I have been mounting a case for law (in its wide-scope dutyimposing aspects anyway) to track morality, and for it to track criticalnormative morality rather than purely conventional-positive morality. The reasons I have offered are purely pragmatic ones: that is the best way to give people in general epistemic access to the content of the law which is supposed to guide their conduct. That is an important pragmatic consideration. But of course there may be other countervailing considerations, pragmatic or principled, pointing even more powerfully in other directions. So, to reiterate, the reasons I have been giving should certainly be regarded as purely pro tanto reasons.

To say that law should 'track morality' is, strictly speaking, to suggest that the law should prescribe or proscribe an act if and only if morality (by which I mean critical-normative morality) prescribes or proscribes that act. That is the way the phrase, and legal moralism more generally, is most readily regarded. I shall go on to explain why that bi-conditional is not exactly correct in either direction. But let me first explain why, from the perspective I have here been exploring, the bi-conditional is broadly correct in both directions.

Why might we think it is a good idea for lawmakers to write all and only morality into the law? Remember my focus: epistemic access. Lawmakers want citizens to know what the law requires, so that citizens can align their conduct with the requirements of law. Deviating from the bi-conditional in either direction would undermine citizens' confidence in the inference that such lawmakers are hoping that citizens will rely upon, namely, 'If it's immoral, then it's probably illegal too'. From that point of view, it is just as bad to make illegal something that is morally innocuous as it is to fail to make illegal something that is morally obnoxious. Either way, you undermine people's confidence in the inference upon which lawmakers following my advice would be relying upon, in order to give citizens easy epistemic access to the content of the law.

That said, I must go on to say that there can sometimes be good reasons for the law to deviate from that bi-conditional in each direction. In the next section I shall discuss reasons why some things that are morally required should not be legally required as well. First let me dispose of the easier case of imposing legal requirements where there are no moral ones.

Of course, many of the statutes that are pilloried as 'ludicrous laws'-the laws against dying inside the British Houses of Parliament and against naming a pig 'Napoleon' in France and such like-are deemed ludicrous precisely 
because they make illegal acts that are not remotely immoral. ${ }^{42}$ Likewise, complaints with 'overcriminalization' often amount to complaints that things have been made illegal that are not immoral (or anyway that the legal penalties are far in excess of any moral wrong). ${ }^{43}$

In some cases, however, there are good reasons legally to require something that morally is not required. That happens every time lawmakers stipulate one of those 'arbitrary' elements of the code, where some stipulation is important for social coordination but where any of several stipulations would be equally good from a moral point of view. When the law requires something that morality does not in this way, citizens cannot infer what the law is from reflecting on what morality requires: as I have said, citizens just have to go look up the law, in those cases. That is an epistemic cost that is inevitably incurred, whenever law must stipulate something where morality is silent.

9.

Turn now to the other, harder half of the bi-conditional. Having seen cases where law need not instantiate only morality, can we not also find cases where law need not-indeed, should not-instantiate all of morality, even in its critical-normative form?

Is there not a realm of activities that ought be regarded as 'private', beyond the reach of the law? That, of course, is the question at the heart of the classic debate over the legal enforcement of morality. ${ }^{44}$ What Hart and Devlin were debating, after all, was whether homosexuality should be illegal just because it is immoral-as both of them supposed it to be for the sake of that argument. ${ }^{45}$

The first thing to say is, of course, that that is itself a judgment of conventional 1950s morality that might not withstand scrutiny of critical-normative morality. But let us set that issue to one side to try to get at the larger structure of the argument in play.

When we say, with Hart and Mill, that there are certain things that ought be regarded as private and not subject to legal regulation, note that that is itself a claim within critical-normative morality. If Hart and Mill are right in their reading of critical-normative morality on that score, then there is a reason within critical-normative morality not to enact all of critical-normative morality into law.

When enacting critical-normative morality into law, it is right-from the point of view of that critical-normative morality itself-for lawmakers not to

\footnotetext{
42 BBC "UK Chooses "Most Ludicrous Laws", BBC News, 6 November 2007 <http://news.bbc.co .uk/go/fr/-/2/hi/uk_news/7081038.stm> accessed 20 May 2010.

${ }^{43}$ D Husak, Overcriminalization (OUP, New York 2007).

44 Indeed, HLA Hart, Law, Liberty and Morality (Stanford UP, Stanford 1963) 4 defines the issue in terms of this half of the bi-conditional: 'Is the fact that certain conduct is by common standards immoral sufficient to justify making that conduct publishable by law?'

${ }^{45}$ Hart, ibid; P Devlin, Enforcement of Morals (OUP, Oxford 1965).
} 
enact into law those elements of critical-normative morality that that morality itself says not to enact. Insofar as law tracks critical-normative morality, and insofar as citizens know that that critical-normative morality contains this clause, citizens surmising what is legally required on the basis of what is morally required would not expect those aspects of morality to figure in the statute books. ${ }^{46}$

Of course, whether or not critical-normative morality contains such a clause is precisely the point under debate between Hart and Devlin. Just as with other elements of contested morality, here likewise: from the fact that that debate is occurring, citizens should know that they cannot trust their own intuitions about what is morally right and wrong as a good guide to what might be legally permissible or impermissible. They better go check which interpretation of critical-normative morality actually got written into the law. Still, the fact that an act is arguably immoral, in ways that are arguably fit for legal regulation, gives everyone fair notice that they had better check the letter of the law; and telling everyone that they had better think twice before behaving in ways that are arguably immoral is no bad thing, surely.

\section{0.}

As regards the status of this analysis, I am inclined to be non-committal. It might be seen a reformist proposal, insofar as law (at least in its wide-scope duty-imposing form) does not currently track broad, general principles of critical-normative morality. That was certainly the orientation of Bentham, and a raft of law-reformers in his wake. Alternatively, my analysis might be seen as sociological hypothesis: insofar as law succeeds tolerably well in discharging its social function of guiding the actions of those ruled by it, law probably does (at least within that realm) track some broad, general principles of criticalnormative morality that are intuitively accessible to citizens who infer the law on that basis.

Whichever way it is seen, however, I am obliged to provide some account of legal change. For if law should (still less, does) track the timeless truths of critical-normative morality, it seems to be something of a mystery why law does (and still more, why it should) change over time.

Part of the answer is simply this. The broad, general principles of critical-normative morality may themselves be timelessly true. But their

\footnotetext{
46 As an analysis of what laws should be enacted, there would be something worryingly tautological about the injunction, 'Enact what should be enacted.' But that is not what I am saying here. Instead, I am saying, 'Enact what critical-normative morality says should be enacted.' I am merely fleshing that out by saying, 'That is to say, legally require something if and only if critical-normative morality requires and critical-normative morality does not require that it not be legally required.'
} 
application depends upon further facts about the world. Those facts, and especially our understandings of them, alter over time. So the same principles play out differently in different times and places.

Hence, critical-normative morality partakes of some of the same elements as positive-conventional morality. Even if we are trying to apply critical-normative principles that are perfectly broad and general in scope, we must apply them to the particular circumstances of our society - and lawmakers must apply them to those circumstances as they are generally understood within their society, if they are trying to make law track morality for the epistemic purposes here in view. As those circumstances and the general understanding of them change, law changes.

This is not the same as law tracking positive-conventional morality as such, however. It is not a matter of letting law track whatever prejudices happen to be prevalent around here at the moment. Law, on this account, would still be tracking broad, general principles of critical-normative morality; and those are readily accessible to everyone, from the armchair (at least for one who does not lead one's whole life in the armchair). It is just that what in particular those laws require will depend on how those broad, general principles apply in the particular circumstances of the society.

To surmise how those particulars got filled in by lawmakers attempting to maximize citizens' epistemic access to their laws, citizens will also need to know what lawmakers thought citizens in general thought about how those principles apply in the particular circumstances of their society. But citizens need to know only half as much, in working that out, as they would need to know in order to surmise the content of law based on positive-conventional morality pure and simple. Where law tracks 'applied critical-normative principles', the critical-normative principles still provide a useful epistemic shortcut for citizens, even if they need some of the same more 'local' knowledge in surmising how they would have been 'applied' as they would need to surmise the content of law had it been based on positive-conventional morality altogether.

\section{1.}

To suggest that there are epistemic advantages in law tracking morality is not a wholly novel thought. Nineteenth-century jurisprude John Austin observed similarly:

Some laws are so obviously suggested by utility [his standard of morality], that any person not insane would naturally surmise or guess their existence... And most men's knowledge of the law is mostly of this kind. They see that a particular act would be mischievous, and they conclude that it must be prohibited. The conduct of nineteen 
men out of twenty, in nineteen cases out of twenty, is rather guided by a surmise as to the law, than by a knowledge of it. ${ }^{47}$

A century later, Ronald Dworkin said something similar in his discussion of the 'integrity' of law. ${ }^{48}$

Both Austin and Dworkin pass over this point quickly, dismissing it as merely 'practical'. ${ }^{49}$ To my mind, however, those practicalities are fundamental. For law to serve its social function-for it to guide people's action, to point and to push them in directions legally desired-people have to have some good way of finding out what the law actually requires of them. One good way of enabling them to do so is for law, in its most general wide scope, duty-imposing aspects anyway, to track broad general principles of critical-normative morality. It may be the lowliest rather than loftiest reason for law to track morality. Such low-level considerations, however, are often the most practically decisive.

47 Austin Lectures on Furisprudence (n 6) Lect 25, 501. Notice that this question of "what is the law on this matter?'-even where that question is answered (as Austin and I would do) in terms of 'what is the pronouncement of morality on this matter?'-is a very separate from 'what social order would have emerged on this matter in the absence of law?' The answer to the latter question requires consideration of what extra-legal sanctions can be brought to bear, whereas the answer to the first two questions requires consideration only of what (moral) order legal sanctions ought to get behind. See RC Ellickson, Order Without Law (Harvard UP, Cambridge, Mass 1991).

48 'If people... are governed not only by explicit rules laid down in past political decisions but by whatever other standards flow from the principles these decisions assume, then the set of recognized public standards can expand and contract organically, as people become more sophisticated in sensing and exploring what these principles require in new circumstances, without the need for detailed legislation or adjudication on each possible point of conflict'; R Dworkin, Law's Empire (Fontana, London 1986) 188.

49 Ibid 189. 